\title{
Playing AND LAUghing gods of Plato's dialogueS IN THE COMMENTARIES OF PROCLUS
}

\author{
DMITRY KURDYBAYLO \\ Russian Christian Academy for the Humanities \\ The Herzen State Pedagogical University of Russia \\ theoreo@yandex.ru \\ INGA KURDYBAYLO \\ The Bonch-Bruevich Saint-Petersburg State University of \\ Telecommunications, inga.posta@mail.ru
}

\begin{abstract}
Socrates' irony" is a well-known topos. Dialogues of Plato contain different modes of humour, from mild self-irony to quite sarcastic tones. Plato's gods are 'playful,' they treat people as those were 'playthings.' The best way of mortals' life is to play also, spending their time in "sacrificing, singing, and dancing." However, Neoplatonic commentaries to Plato tend to avoid explicit laughter and any direct mode of humour. Proclus, one of the most fruitful commentators of Plato, seems to disregard anything ludicrous in Plato's writing. The places, where Plato speaks about laughter or playing games, are explained by Proclus as signs to some kind of divine activity towards the material realm. Even smile and laughter of particular humans are interpreted in the same way as symbols (synthemata) of gods' providence. What Proclus discusses in minor details, is the dialectics of gods' procession into the sensible world, causing substantiation of the universe, and retention of the internal bonds that keep it eternal and unchangeable. Similarly, temporary particular beings also benefit from divine providence, which fortifies their vital capabilities. In general, these forms of providence are depicted by "the undying laughter" of gods. In spite of this approach seeming to be superfluously 'scholastic' and therefore losing the dramatic perspective of Plato's writings, we suggest that Proclean interpretation may assume laughter to be related to some theurgic practice. Therefore, reading and interpretation the game- and laughter-related passages of Plato could have been considered themself a kind of theurgic "sacred play."

KeYWORDS: Plato, Proclus Lycaeus, Neoplatonic commentary, providence, metaphysics, game, laughter, humour.

* The research was supported by the Russian Foundation for Basic Research project No 19-011-00749 "Symbol between the ridiculous and the serious in Byzantine exegetics."
\end{abstract}

¿XOAH Vol. 15. 1 (2021)

classics.nsu.ru/schole/
(C) Dmitry \& Inga Kurdybaylo, 2021 DOI:10.25205/1995-4328-2021-15-1-53-63 
In a preface to a large Platonic commentary of Proclus Lycaeus, Dirk Baltzly has noticed: "His ontology is out of this world, his syntax often inscrutable, and his ear for Plato's humour and playfulness is tin" (Baltzly 2007, viii). The latter statement is intuitively evident to almost every scholar of Proclean writings. Scholars of ancient humour do not consider Proclus as an interpreter of Socrates' irony at all (Heath 2019), or just mention that he "did not recognise" Plato's humour (Tanner 2017, 103). However, for Proclus, a profound scrutator of Platonic thought, it is highly probable to expect some regularity in converting "ludicrous" passages of Plato's dialogues into "serious" narrative of Neoplatonic commentary.

Before starting comparing Plato's texts and their interpretations of Proclus, it is necessary to state that there is a serious difficulty in defining what was considered laughable either by Plato's and Proclus' contemporaries. What is usually referred to as "Socratic irony," is often asserted to be "ironic" from a modern reader's standpoint. Below I am going to discuss only the passages explicitly related to some sort of humour in the text under analysis. The most frequent case in Proclus' commentaries is when Plato's characters mention "laughter" ( $\gamma \dot{\varepsilon} \lambda \omega \varsigma)$, "toys" $(\pi \alpha i \gamma \nu \downarrow \alpha)$ or "playing games" ( $\pi \alpha i \zeta \varepsilon \imath \nu)$. Also, like with many other subjects, Proclus has a shortlist of the most important Plato's fragments, which are mentioned many times; and on the contrary, less notable passages are commented upon just once or twice over the whole corpus of extant Proclean writings. Several examples of such passages will be discussed below.

\section{Mundane life as a stage play}

Firstly, one may notice that playing games in the sense of $\pi \alpha$ เo $\delta$ í is accepted by Proclus as something inherent to human nature. One of the widely known metaphors of the human realm as a theatre play was introduced centuries before Proclus. ${ }^{1}$ Plotinus elaborated on this metaphor in the Enneads 3.2.16-18, comparing humans with stage players, the whole life of the mundane world with a drama, and the universal logos with a playwriter. ${ }^{2}$ In the same treatise, Plotinus opposes the stage playing $(\pi \alpha i \zeta \omega)$ to being serious ( $\sigma \pi \circ v \delta \alpha \hat{\imath} \varsigma \varsigma)$, and moreover, he considers people who are just actors on a stage but take the play seriously as it were a real life:

${ }^{1}$ In addition to the fragment of the Enneads discussed below, confer Heraclitus' identification of eternity ( $\alpha i \omega \dot{\omega}$ ) with "a playing child" (DK B52 = frg. 154 [F1o9] in: Graham 2010, part 1, 178-179), Epictetus' evidence of Socrates "playing ball" at his trial (Dissert. 2.5.18, Schenkl 1965), and Plato's depiction of the life in his ideal State as "the finest tragedy" ( $L g$ 817b2-3). Hellenistic period provides numerous examples of similar thinking.

${ }^{2}$ Plotinus, Enn. 3.2.17.28-37. Below Greek text of the Enneads is quoted from: Henry, Schwyzer 1951, and English translation from: Gerson 2018. 
...in the sensible world in each aspect of our lives, it is not the inner soul but the outer shadow of a human being that wails and laments and does everything on the stage which is this whole earth ( $\dot{\varepsilon} \nu \sigma \kappa \eta \nu \hat{\eta} \tau \hat{\eta} \bar{o} \lambda \eta \eta \hat{\eta})$ as we set up our individual stages in many a place. For these are the deeds of the human being who knows how to live only the lower and external life and does not realize that even when his tears are seri-

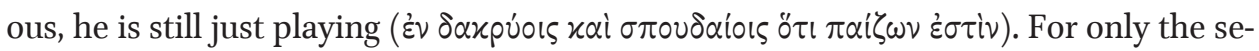

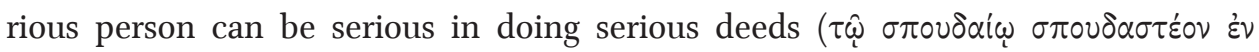

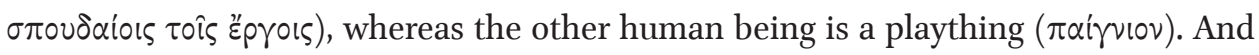
even playthings are taken seriously by those who do not know how to be really serious and are themselves playthings. But anyone who joins in their play and has that kind of experience, should know that he has fallen into a child's game $(\pi \alpha i \delta \omega \nu \pi \alpha i \delta \hat{\alpha})$ and has put aside the garment in which he is clothed. ${ }^{3}$

In other words, the playful and the serious sides of being are closely related to the distinction of temporal and eternal, which finally leads to the opposition of sensual to intelligible. However, if it is almost impossible to take erroneously sensible for intelligible, one can easily take playfulness for seriousness. This difference reveals the delusive and addictive nature of game-playing, according to Plotinus.

What still stays unexplained, is what kind of "playthings" Plotinus is speaking about? Proclus provides us with further insight into the subject while commenting the words from Plato's Parmenides 137b2 about "playing out this laborious

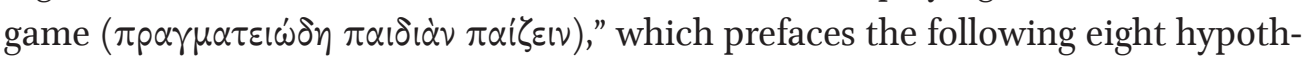
eses. Why the refined dialectics of the Parmenides can be called a game, is a problem which is solved by Proclus as follows:

Parmenides utters ... the phrase "to play out this laborious game" ... in imitation of the divinity ... This also is divine, to call his clear and many-faceted procedures

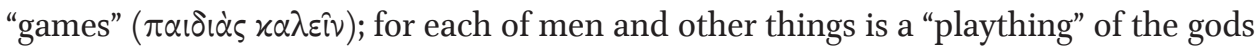

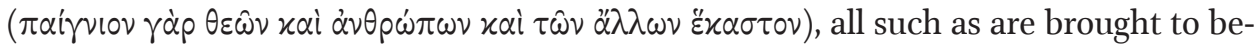
ing by their outgoing energies. Every external argument is thus a "game," compared to

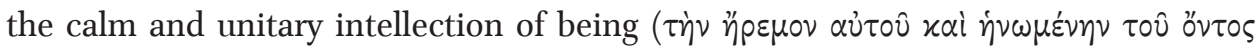
vón $(v)$, but it is nevertheless "laborious" because it has to do with the contemplation of real beings, and unfolds the simplicity of the intellection within. ${ }^{4}$

John Dillon suggests that "a plaything of the gods" is borrowed from Plato's Laws 803c4-5, where humans are called gods' playthings: $\alpha v \theta \rho \omega \pi \circ \nu$... $\theta \varepsilon \circ \hat{\nu} \tau$

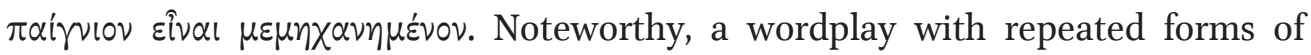

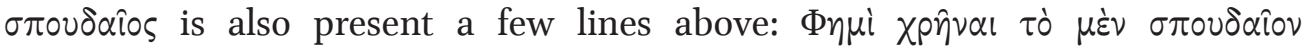

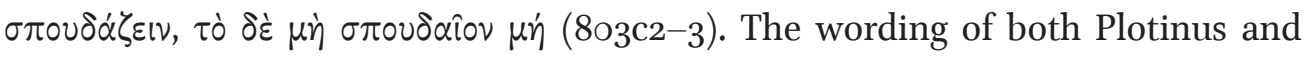

\footnotetext{
${ }^{3}$ Plotinus, Enn. 3.2.15·47-58; Gerson 2018, 268.

${ }^{4}$ Proclus, in Parm. 1036, lines 2-12, Cousin 1961; English translation: Dillon, Morrow 1987,382 .
} 
Proclus is so close to Plato's phrases that it is difficult to deny that both allusions to the Laws were intentional and deliberate.

While Plato argues that the life of each human should be "spent at play," Proclus extends this rule to the life of the whole cosmos as a universal principle:

Since the universe is one living thing, it is sympathetic with itself, so that all the

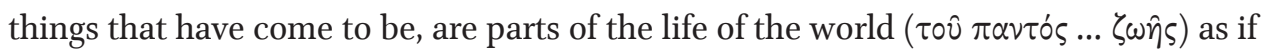
it were a single drama - for example if there were some tragic poet who created a drama in which visitations from gods, voices of heroes and other players [were introduced], and he assigned to those among the actors who were willing some heroic speech or other part, while he himself encompasses within himself the single cause ( $\tau \dot{\eta} \nu \mu i \alpha \nu \alpha i \tau i \alpha \nu)$ of all that is said. ${ }^{6}$

The following phrases emphasise that the plurality of the sensible cosmos is united into a whole living entity by the World Soul, who is compared with a playwriter in the same way as the mundane life is called a drama. The main objective of Proclus here is that from the divine standpoint, each kind of multitude, diversity and difference between the "actors" is brought to simplicity and identity in the gods' ("playwriter's") knowledge.

One of the main premises in these passages implies that multiplicity, diversity and complexity of the material realm are somehow correlated with the playing either on stage or some other kind of game-playing. Proclus develops further his dialectics of one and multiple suggesting that what is ridiculous, absurd or ludicrous should be related to plurality and pertain "to the region of the indefinite

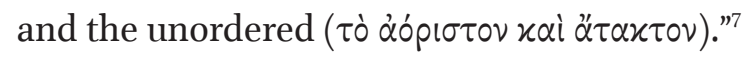

\section{Gods' providence towards the universe}

Proclus elaborates on Plato's' "plaything of gods" from the Laws 8o3c adding Homeric imagery of "undying laughter" of Olympic gods. ${ }^{8}$ Probably, the clearest explication of Proclus' views on these subjects is given in a dedicated paragraph (Essay 6, § 12) of the commentary on Plato's Republic:

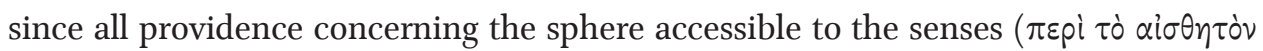
$\left.\pi \rho \operatorname{vov}^{\prime} \alpha\right)$... is called the "play" of the gods $\left(\pi \alpha \_\delta i \alpha \nu \tau \hat{\omega} \nu \theta \varepsilon \hat{\omega} \nu\right)$ - and for this reason, I believe, Timaeus calls the encosmic gods "young" (vદ́ovऽ, Tim. 42d6), since they are set over things that are continually coming into being and are properly playthings

\footnotetext{
${ }^{5}$ Plato, $L g$. 803e1-2: "A man should spend his whole life at 'play' - sacrificing, singing,

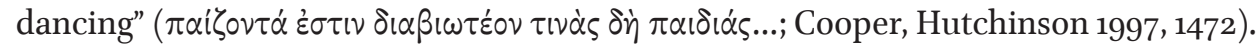

${ }^{6}$ Proclus, in Tim., 2.305.7-14, Diehl 1965; English translation: Baltzly 2009, 306.

${ }^{7}$ Proclus, in Parm. 717.28-35; Dillon, Morrow 1987, 89.

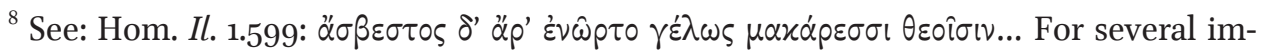
portant notes on this passage see a recent article by Shcherbakov 2021.
} 
( $\pi \alpha \iota \delta i \hat{\alpha} \varsigma \dot{\alpha} \xi i \omega \nu \pi \rho \circ \varepsilon \sigma \tau \hat{\omega} \tau \alpha \varsigma \pi \rho \alpha \gamma \mu \alpha \dot{\tau} \tau \omega \nu)$ - the mythoplasts are accustomed to designate the specific quality of this providence of the gods that act within the cosmos as

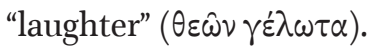

... The laughter of the gods is to be defined as their generous activity within the

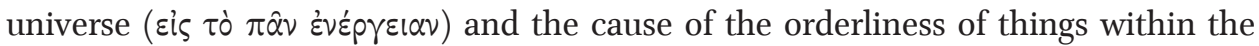
cosmos $(\tau \hat{\omega} \nu \dot{\xi} \gamma \varkappa o \sigma \mu i(\omega \nu)$. It must also be conceded that because such providence is unceasing $^{9}$ and the giving of all good things by the gods is inexhaustible, the Poet chose quite rightly to add that their laughter was "undying ( $\alpha \sigma \beta \varepsilon \sigma \tau o v)$ )" You can see again that these explanations are in line with the nature of things: the myths do not make the gods weep incessantly, but they do say that they laugh unrestrainedly, because their tears are symbols ( $\sigma \nu v \theta \eta \dot{\eta} \mu \tau \alpha)$ of their providence toward mortal and perishable things, things that exist at one time and at another do not, while their laughter [is symbolic] of the activity that extends to the universals that fill the universe and are constantly in motion with the same movement.

This, I think, is why, when we divide the creation of the demiurge into gods and men, we allocate laughter to the birth of the divine but tears to the emergence of men and beasts. ${ }^{10}$

The discourse becomes even more complicated: while playing and games pertain to the sensible and perishable realm of humans, the laughter is proper to gods. However, the laughter is related to gods' activity directed to the sensible realm, which is taken universally as a singular and perpetual whole. In the same way "playthings" are those, which "are continually coming into being ( $\dot{\varepsilon} \varepsilon$

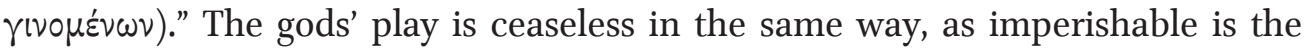
universe as a whole.

There are several other passages, where Proclus interprets the endless laughter of gods as their providence. Commenting Plato's Timaeus, Proclus emphasizes that the universe has "genuinely inerrant" movement, and "perpetually" exhibits "the same uniform revolution," thus imitating the motion of the intellect. Exactly this whole and eternal cosmos is considered to be the subject of gods' providence, represented by "unquenchable laughter." ${ }^{\text {"11 }}$ Another passage provides more details on how the providence affects the universe:

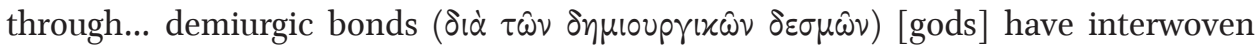
sameness with difference, harmony with separation, and association with opposition. And Apollo laughs at them, and Hermes laughs, and each of the gods laughs (Od.

\footnotetext{
${ }^{9}$ On varia lectio at this place see: Lamberton 2012, $169 n 197$.

${ }^{10}$ Proclus, in Rem. Pub. 1.127.4-128.7 (Kroll 1899), English translation: Lamberton 2012, 167-169. For parallels of this passage with writings of Syrianus and Hermias see: Sheppard 1980: 81-82.

${ }^{11}$ Proclus, in Tim. 2.98.2-13; Baltzly 2007, 160-161.
} 


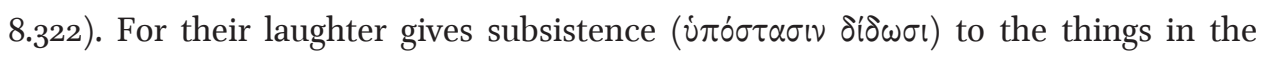
cosmos and puts power in the bonds. ${ }^{12}$

Naturally, "giving subsistence" and "putting power in the bonds" do not exhaust all the possible manifestations of god's providence, since there are numerous relevant examples, both of Proclus and of his predecessors (especially Iamblichus $\left.^{13}\right)$. Nevertheless, none of them is related to laughter or playing games in Proclean writings.

One more passage identifies some kind of gameplaying with the Demiurge's "providential activities towards his recently fashioned works." ${ }^{14}$ Several lines later, Proclus explains that providence about the sensible cosmos is called "game" when compared to the utmost seriousness of the realm, which transcends it.

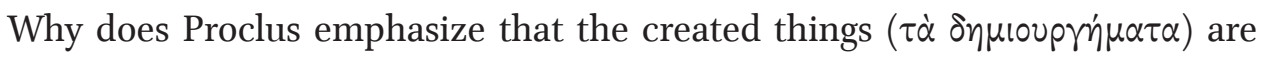

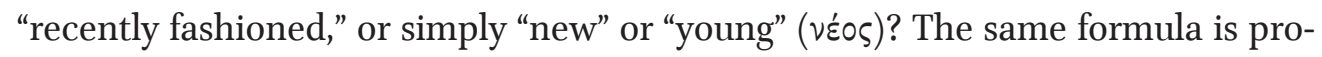
vided more once in a more verbose manner:

The Egyptian compares the solemn and ancient narratives of Solon with childish sto-

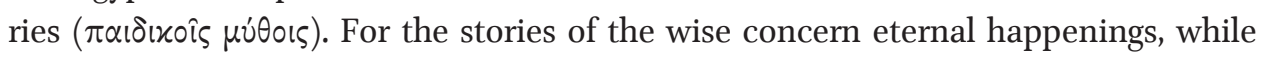
those of children concern minor temporal matters; and the former have a hidden truth that is intellective, while the latter have one that is down to earth and gives no indication of anything elevated....

Beginning with these [two kinds] we should consider their paradigms, [noting]

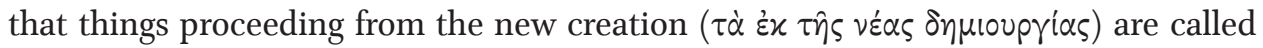
'playthings of the gods' and resemble myths. For they are images of realities $(\varepsilon i \delta \omega \lambda \lambda \alpha$

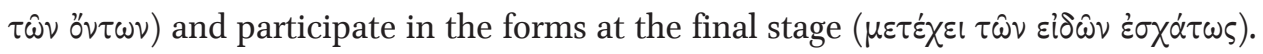

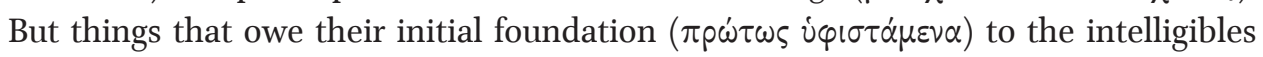

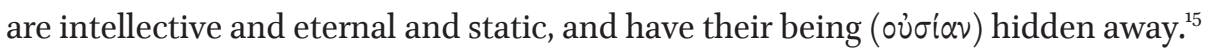

This wording allows one to expect that things, which proceed from the "new" or "recently fashioned" creation, have limited temporal existence as opposed to the eternal being of the intelligibles. This opposition is expressed by antinomic pairs

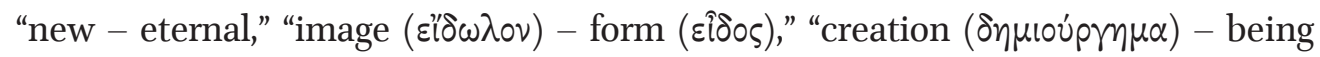
(oj $\sigma^{\prime} \alpha$ )." However, some kind of "old creation" is also possible from such a standpoint: the universe as a whole, simultaneously is a $\delta \eta \mu$ iópm $\mu \alpha$ and is eternal.

\footnotetext{
${ }^{12}$ Proclus, in Tim. 2.27.22-28; Baltzly 2007, 73-74.

${ }^{13}$ Iamblichus divides the gods' activity towards the universe into two types: demiurgy and providence, which are supplemented by divination; see: De mysteriis 3.16.45, 3.17.27, 3.19.17-21. In Proclus, for instance, divine providence corrects humane mistakes in namegiving: in Crat. 88.1-17. For more on providence in Proclus see: Opsomer, Steel 2014, 1-59.

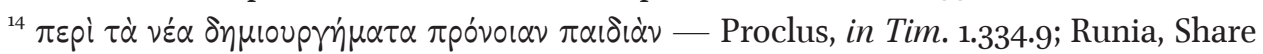
2008, 190 .

${ }^{15}$ Proclus, in Tim. 1.127.4-18; Tarrant 2006, 222-223.
} 
Here, Proclus again states that "playthings of the gods" are "minor temporal matters," and that they do not provide reliable knowledge about the intellectual realm. ${ }^{16}$ The "forms at the final stage" which they participate in, are the forms of the lowest level in the intellectual hierarchy, at its very "edge" ( $\tilde{\sigma} \sigma \alpha \tau \circ \nu)$.

\section{Dialectics of remaining, procession, and reversion}

In Proclean ontology, gods' providence is closely related to the dialectic triad

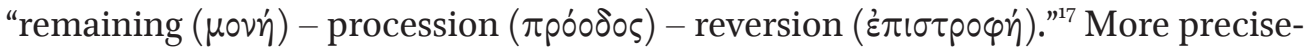
ly, the providence is a particular kind of gods' procession to the lower hierarchical levels. As we have recently read, gods' laughter and gameplaying are directed towards the lower inner sphere of the universe, thus the corresponding starting point of such procession should also be located at some low level. This assumption agrees with the following statement of Proclus:

The youth seems to pose questions about the lord Dionysus as if about a trifling matter, and this is why he is reprimanded by Socrates (Crat. 406b8-c1), and does learn from him

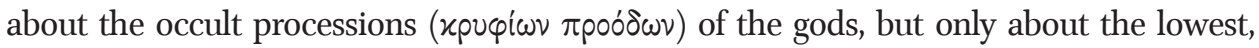
encosmic ones. Of course, the wise man takes these things seriously as well, although they are "playthings" (Laws 803c5), as he says, since "these gods are playful" (Crat. 406c2-3). For as he says that the limits of the other gods, though they are frightening, vengeful, and punitive, perfect particular souls.... In the same way he glorifies the limits of Dionysus and Aphrodite which produce spiritual delight. ... In fact, it is because he fortifies anew the weakness of mortal nature and relieves the difficulty of corporeal life that the gods

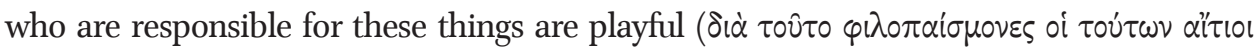
$\left.\theta \varepsilon i^{\prime}\right)$. Whence, no doubt, they make the one class of statues laughing, unrestrained, and dancing, but the other harsh, daunting to those that view them, and fierce, by analogy to the encosmic lots of the respective gods. ${ }^{18}$

This passage leads to three conclusions. Firstly, the teaching about gods' laughter and playing refers to the lowest, encosmic order of gods only. Secondly, some of these gods are playful; they are depicted "laughing, unrestrained, and dancing." Finally, this imagery corresponds to their activity towards mortal beings, who receive relief and fortification from these gods. Naturally, this activity can be called some sort of providence, and this sort of providence appears to be a kind of procession, which is not "occult," or concealed in any way.

Commenting upon Plato's Parmenides, Proclus pays much attention to a dia-

\footnotetext{
${ }^{16}$ Ibid., lines 12-13.

${ }^{17}$ On this triad and its origins in Proclus' philosophy see: Gersh 1973, 49-53; Chlup 2012, 64-69.

${ }^{18}$ Proclus, in Crat. 181.1-23, Pasquali 1908; English translation: Duvick, Tarrant 2014, 104. On the authenticity of this paragraph see: Duvick, Tarrant 2014, 3-4.
} 
logue between Zeno and Parmenides, when one of them laughed, and the other smiled. Laughter and smile appear to be symbols of quite different matters:

The smile, then, represents ( $\mu \mu \varepsilon i \tau \alpha \iota)$ the invisible and hidden activity of the divine

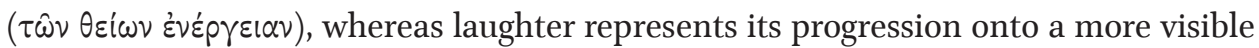

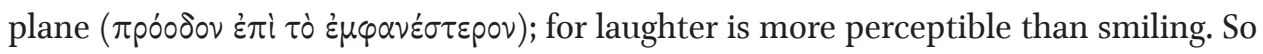
the one represents the permanent and quiescent and hidden god, the other a god who remains above ( $\dot{\delta} \delta \dot{\varepsilon} \tau \dot{\delta} v \alpha \tilde{\alpha} \omega \omega \mu \dot{\varepsilon} v o v \tau \alpha)$, but is already in the process of proceeding

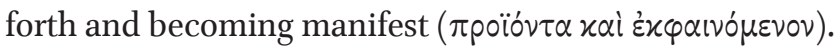

And there is something more remarkable still than this. Zeno, when he smiles, looks at Parmenides, ... but when he laughs, he addresses himself to Socrates. This is because in the divine realm the mediating class is hidden in so far as it is united with what is above it, but becomes manifest in so far as it consorts with what is below it. So therefore when Zeno laughs, he is manifesting himself to Socrates by ranking himself with him, through this union calling forth the thought of Parmenides. ${ }^{19}$

Here the laughter is clearly associated with procession, which is directed from an upper level to a lower one. In the same way, smiling is related to "invisible and hidden" activity, which is not related to any procession and is represented by a movement in an upward direction. Also, this is the only instance of human laughter discussed by Proclus (all others described laughing gods).

\section{Possible definitions of laughter and play}

Now we can try to compose general formulae:

- divine laughter is proper to lower encosmic gods only. This laughter is a kind of gods' procession into the sensible realm as it is distinguished from remaining and reversion. It is always directed from an upper level of the ontological hierarchy towards its lower level. The procession is further defined as gods' providence towards the universe as a whole and towards particular beings. When this providence is directed towards the whole universe, it keeps the subsistence of the eternal cosmos and the power of bonds, which connect opposite qualities of the cosmos in an immutable harmony. When the providence is directed to particular bodily creatures, who have temporal being with definite beginning and end, gods fortify and renovate their lives;

— divine "playthings" are material temporal beings, i.e. humans and other particular sensible creatures. The universe as a whole is never called a gods' plaything. Encosmic gods make up the only order of gods, some of which can be called "playful" properly. Not all the encosmic gods are playful, and none of the gods of other orders is playful (at least, in the word's proper sense);

\footnotetext{
${ }^{19}$ Proclus, in Parm. 1022.24-41; Dillon, Morrow 1987, 370-371.
} 
— playing is the proper activity for people, or, possibly, for all mortal beings. However, a wise man is the one, who can distinguish the playful mode of the earthly life from the substantial seriousness of the intellectual realm.

\section{Proclus and Plato's humour}

Now let us recall Dirk Baltzly's notice mentioned at the beginning of this text. None of Proclus' quotations above read Plato's humour as humour proper. He mentions laughter, smile, games and playthings, but it seems that neither Proclus, nor his readers are expected to smile or laugh themselves at Plato's text. One explanation of this fact is obvious: Plato's dialogues centuries before Proclus became the utmost authority for Platonists, and Plato himself was called divine. The more Platonic heritage was becoming sacral, the less it was possible to laugh at it, even if certain places in the text were clearly ludicrous.

However, there is another, less obvious side of Proclus' prominent "seriousness." Almost all abovementioned fragments of Proclean writings discussed gods laughing and playing with their "playthings," and only the episode with Parmenides and Zeno provided an example of human laughter and smile. However, the interpretation of human laughter is provided exactly in the same exegetic pattern, which is used for divine laughter. In other words, for Proclus, the laughter itself is more important than who is exactly laughing, a mortal being or a deity.

The second important hint is provided in the $12^{\text {th }}$ paragraph of the $6^{\text {th }}$ Essay of Proclus' commentary on the Republic. As quoted above, tears and laughter of gods symbolize two modes of their providence, or more precisely, they are $\sigma v v \theta \eta \dot{\eta} \mu \alpha \alpha$. Synthèma is a special term of Neoplatonic metaphysics, and Proclus clearly distinguishes it from close notions such as 'symbol' or 'image. ${ }^{.20}$ Both symbols and synthèmata are closely connected with the dialectics of procession and reversion. However, synthema is more close to the downward, processive direction, while symbol is the most expressive entity and starts the upward movement, i.e. the reversion. ${ }^{21}$ Synthema is introduced in the scope of hierarchical causal series (or

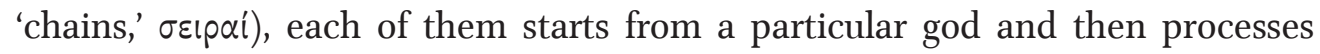
downwards till the lowest material stage. ${ }^{22}$ Every substance that belongs to a certain series has some "token" as an ontological bond with the generating god. Such a "token" is exactly what is called synthēma in Greek.

If according to Proclus, the laughter is a synthēma of gods' providence, and if

\footnotetext{
${ }^{20}$ In spite of some scholars deny such distinction in Proclus, there are a number of influential works supporting this standpoint, see: Dillon 1975, Trouillard 1981, Cardullo 1985. For other references see: Kurdybaylo 2019.

${ }^{21}$ Kurdybaylo 2019, 482-483.

${ }^{22}$ On causal series or "chains" in Proclean metaphysics see: Gersh 1973, 67-69.
} 
both human and divine laughter have similar significance, then at least some kinds of human laughter could also be synthèmata of divine providence.

It means that reading Plato's description of gods' play or laughter, which in turn reproduce Homer's narrative, Proclus suggests a way of transferring described playfulness into some divine context. This practice itself is quite close to the theurgic discovery of divine symbols, which afterwards lead the human soul to the intelligible. ${ }^{23}$

In other words, what seems Proclus' insensibility to Platonic humour, may actually be a kind of theurgic practice, introduced inside an exegetical procedure, i.e. the philosophical commentary. And symmetrically, the procedure of commenting itself becomes a kind of theurgic practice from this standpoint. In any case, rites and sacrifices are a kind of gameplaying for Plato. ${ }^{24}$ More precisely, it is a sacred game ${ }^{25}$ which cannot be separated from theurgy in a Platonic perspective.

\section{REFERENCES}

Baltzly, D., tr., ed. (2007) Commentary on Plato's Timaeus, vol. 3, book 3, pt. 1: Proclus on the World's Body. Cambridge: Cambridge University Press.

Baltzly, D., tr., ed. (2009) Commentary on Plato's Timaeus, vol. 4, book 3, pt. 2: Proclus on the World Soul. Cambridge: Cambridge University Press.

Cardullo, R. L. (1985) Il linguaggio del simbolo in Proclo: Analisi filosofico-semantica dei termini symbolon / eikôn / synthêma nel Commentario alla Repubblica. Catania: Università di Catania.

Chlup, R. (2012) Proclus. An introduction. Cambridge: Cambridge University Press.

Cooper, J.M., Hutchinson, D.S., eds. (1997) Plato. Complete Works. Indianapolis, Cambridge: Hackett Publishing Co.

Cousin, V., ed. (1961) Procli philosophi Platonici opera inedita, pt. 3. Hildesheim: Olms (repr. of 1864 ed.).

Diehl, E., ed. (1965) Procli Diadochi in Platonis Timaeum commentaria, 3 vols. Amsterdam: Hakkert (repr. of 1903-1906 ed.).

Dillon, J. (1975) "Image, symbol, and analogy: Three basic concepts of Neoplatonic exegesis," in R. Baine Harris (ed.), The significance of Neoplatonism. Norfolk, VA, 247-262.

Dillon, J., ed. and tr., Morrow, G. R., tr. (1987) Proclus' Commentary on Plato's Parmenides. Princeton, NJ: Princeton University Press.

Duvick, B. M., tr. and ed., Tarrant, H., ed. (2014) Proclus. On Plato's Cratylus. London: Bloomsbury.

${ }^{23}$ Detailed desciption of a soul's ascent with the help of theurgic symbols was elaborated by many scholars of Iamblichus and Proclus. For instance, see: Shaw 1995, 162-216, Finamore 2013 .

${ }^{24}$ 'Sacrificing $(\theta \dot{v} \circ \tau \tau \alpha)$ ' is considered a kind of 'playing $(\pi \alpha i \zeta o v \tau \alpha)$ ' in $L g$. 8o3e1. Cf. also the ritual armed dance of Kouretes called a game, ह̇ंó $\pi \lambda ı \alpha \pi \alpha i \gamma v 1 \alpha$ in $L g .796 \mathrm{~b} 5$.

${ }^{25}$ Many arguments of J. Huizinga on the nature of sacred play seem to be applicable to our case, confer: Huizinga 1980, 18-27 et passim. 
Finamore, J. (2013) "Iamblichus, Theurgy, and the Soul's Ascent," in: Adluri, V., ed. Philosophy and Salvation in Greek Religion. Berlin: de Gruyter, 343-356.

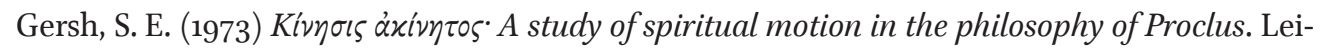
den: Brill.

Gerson, L. P., ed. (2018) Plotinus. The Enneads. Cambridge: Cambridge University Press.

Graham, D. W., tr., ed. (2010) The texts of early Greek philosophy: The complete fragments and selected testimonies of the major Presocratics, 2 parts. Cambridge: Cambridge University Press.

Heath, M. (2019) "Divine and Human Laughter in Later Platonism," in Destrée, P. and Trivigno, F. V., eds. Laughter, Humor, and Comedy in Ancient Philosophy. New York, NY: Oxford University Press, 80-100.

Henry, P., Schwyzer, H.-R., eds. (1951) Plotini opera, vol. 1. Leiden: Brill.

Huizinga, J. (1980) Homo Ludens: A Study of the Play-Element in Culture. London: Routledge \& Kegan Paul.

Kroll, W., ed. (1899) Procli Diadochi in Platonis rem publicam commentarii, vol. 1. Leipzig: Teubner.

Kurdybaylo, D. S. (2019) "On symbolon and synthèma in the Platonic Theology of Proclus," Schole. Ancient Philosophy and the Classical Tradition 13 (2), 463-485.

Lamberton R., tr. and ed. (2012) Proclus the Successor on Poetics and the Homeric Poems: Essays 5 and 6 of His Commentary on the Republic of Plato. Atlanta: Society of Biblical Literature.

Opsomer, J., Steel, C., tr. (2014) Proclus. Ten Problems Concerning Providence. London: Bloomsbury.

Pasquali, G., ed. (1908) Procli Diadochi in Platonis Cratylum commentaria. Leipzig: Teubner.

Runia, D. T., Share, M., eds. (2008) Proclus. Commentary on Plato's Timaeus, vol. 2, book 2: Proclus on the Causes of the Cosmos and its Creation. Cambridge: Cambridge University Press.

Schenkl, H., ed. (1965) Epicteti Dissertationes ab Arriano digestae, ed. maior. Leipzig: Teubner (repr. of 1916 ed.).

Shaw, G. (1995) Theurgy and the soul: The Neoplatonism of Iamblichus. University Park, PA: The University of Pennsylvania State University Press.

Shcherbakov, F. B. (2021) "When Homer ceased to laugh: Epic humor and the ways of its apology in antique allegorism and symbolism," European Journal of Humour Research 9 (1), in print.

Sheppard, A. D. R. (1980) Studies on the $5^{\text {th }}$ and $6^{\text {th }}$ Essays of Proclus' Commentary on the Republic. Göttingen: Vandenhoeck u. Ruprecht.

Tanner, S. M. (2017) Plato's Laughter: Socrates as Satyr and Comical Hero. Albany, NY: SUNY Press.

Tarrant, H., ed. (2006) Proclus. Commentary on Plato's Timaeus, vol. 1, book 1: Proclus on the Socratic State and Atlantis. Cambridge: Cambridge University Press.

Trouillard, J. (1981) « Le symbolisme chez Proclos », Dialogues d'histoire ancienne 7, 297-308. 